\title{
A visual representation of cattle movement in Ireland during 2016
}

\author{
Guy McGrath ${ }^{*}$ D, Jamie A. Tratalos and Simon J. More
}

\begin{abstract}
The aim of this study was to create a clear visual representation of the live movements of cattle in the Republic of Ireland over the course of the year 2016. The animation created can be viewed online: https://youtu.be/PTCdPMnenBw This animation was created to be a communication tool to enable stakeholders to appreciate the extent of high risk cattle movements (farm to farm, farm to market to farm) in the Republic of Ireland and to highlight the potential role that these movements may play in the spread of infectious diseases of cattle in Ireland from one farm to another.

Keywords: Cattle movements, Marts, Biosecurity, Epidemiology, Disease transmission, Geographical information systems, Animal welfare, Risk
\end{abstract}

\section{Introduction}

In Ireland, cattle movement and trade has been a feature of rural life since at least medieval times. Through the centuries, local fairs (aonach in Irish) and markets (margadh) have played an important role in rural society, with cattle making up the greater part of stock offered for sale $[1,2]$. The trade of live animals remains an important component of the cattle industry and, indeed, the farming way of life. More than half of this trade is through markets ('marts'), the remainder being direct farm to farm sales, some of which are mediated online.

The role of cattle movement in disease spread is well recognised and documented [3-6]. Mee et al. [7] identified a wide range of pathogens that could be introduced through introduction of purchased or leased cattle, including viruses, bacteria and protozoa. These authors highlighted the importance of bioexclusion: preventive measures designed to avoid the introduction of pathogenic infections. In Ireland, important infectious diseases of cattle include bovine tuberculosis, Johne's disease (paratuberculosis), bovine viral diarrhoea (BVD) and infectious bovine rhinotracheitis (IBR). Sayers et al. [8] has identified some of the challenges to biosecurity on Irish farms, including factors that influence appropriate implementation, and Irish information is now available to

\footnotetext{
* Correspondence: guy.mcgrath@ucd.ie

Centre for Veterinary Epidemiology and Risk Analysis, UCD School of Veterinary Medicine, University College Dublin, Belfield, Dublin D04 W6F6, Ireland
}

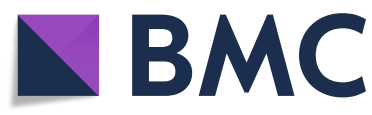

(c) The Author(s). 2018 Open Access This article is distributed under the terms of the Creative Commons Attribution 4.0 International License (http://creativecommons.org/licenses/by/4.0/), which permits unrestricted use, distribution, and reproduction in any medium, provided you give appropriate credit to the original author(s) and the source, provide a link to the Creative Commons license, and indicate if changes were made. The Creative Commons Public Domain Dedication waiver (http://creativecommons.org/publicdomain/zero/1.0/) applies to the data made available in this article, unless otherwise stated.

\section{Methodology}

DAFM's Animal Identification \& Movement (AIM) database contains records of all cattle movements in the Republic of Ireland. This animation presents 1.3 million of these movement events (for example, the movement of a trailer - which may contain a number of cattle - from farm to market), consisting of 6.7 million individual cattle movements (a movement from farm to market and subsequent onward movement to farm are counted as two movements in this study). To maintain farm anonymity, 
herd locations were randomly placed ('jittered') on farmland somewhere within $5 \mathrm{~km}$ of the location of their largest fragment of land. Due to low numbers and the possibility of identification, farms on islands were removed from the study. All movement events between jittered farms and facilities were calculated from the AIM data. Movement events (and by extension, live animal movements) were allocated one of two risk categories according to their potential to facilitate the spread of infectious diseases of cattle in Ireland from one farm to another via live animal movements: 'High Risk' movements, those which concluded in animals being on a farm (shown in red in the animation), including mainly sales via a market and farm to farm sales, but also imports, and 'Low Risk' movements, mainly those which resulted in slaughter but also moves to export points (shown in blue). The number of animals per movement event was also recorded and represented as the size of the place marker disc (or 'dot') at movement start/finish locations. For the national overview, the movement arcs grow at $5 \mathrm{~km}$ per frame, hold for 9 frames and decay over 18 frames - representing a total of approximately 5 days in real-time. For the low altitude scenes, the time is slowed, with the movement arcs growing at $4 \mathrm{~km}$ per frame, holding for 50 frames and decaying over 25 frames - representing approximately a day in real-time. Distances are straight-line calculations and are therefore more conservative than true road-network distances. Distances were calculated for imported cattle from the centre of the country of origin but not for live exports which were only calculated to the point of departure from the Republic of Ireland. Imports from Northern Ireland are designated as United Kingdom imports and therefore appear to originate from mainland Great Britain rather than Northern Ireland in the animation.

\section{Results}

Figures 1 and 2 show screenshots of the animation, which can be viewed online at https://youtu.be/PTCdPMnenBw.

There were 1,314,365 movement events in 2016, of which 1,020,715 (78\%) were 'High Risk' and 293,650 (22\%) 'Low Risk'. These represented, respectively, $6,669,022,4,778,408$ (72\%) and 1,890,614 (28\%) individual animal movements, respectively. Of the 'High Risk' movement events, 375,767 (37.0\%) were movement events from a herd to a market, 388,360 (38.0\%) from a market to a herd, $255,959(25.1 \%)$ from a herd directly to another herd, and $629(0.06 \%)$ of imported animals. These represented 3,511,541 individual animal movements to or from markets, 1,262,596 herd to herd and 4,271 imports. Of the 'Low Risk' movement events, 288,975 (98.4\%) movement events were to slaughter and 4,675 (1.6\%) to export, representing 1,745,044 and 145,570 individual animal movements, respectively.
There was considerable seasonal variation in the 'High Risk' data, which showed distinctive seasonal peaks in Spring and Autumn, with lows in January, July and December, but relatively little seasonality in the 'Low Risk' (Fig. 3). There were in total only 800 'Low Risk' movement events on a Saturday or Sunday, whereas Saturday was one of the busiest days for 'High Risk' movement events (Fig. 4).

\section{Discussion}

Limited studies have been done on cattle movements in Ireland, despite the availability of data on all cattle movements and births going back to the year 2000. To date, this has been limited to investigations of movements in a specific area of Ireland [22] or with specific age groups of cattle [23]. Other studies have used movement data as a component of broader investigations into the aetiology or management of specific diseases [24-28], but as yet, there has been no systematic analysis of cattle movements in Ireland as a whole. This is the first study to provide a detailed, and visual, overview of the magnitude and scope of live cattle movement in Ireland.

Substantial movement of cattle in Ireland has long been recognised. With this, and planned subsequent work, we are now able to present information providing quantitative insights into its magnitude. The 1.3 million movement events shown in the video, representing all journeys travelled by vehicles, such as trailers, to transport cattle to markets, new herds, slaughter plants or export facilities in 2016, cover a cumulative distance of 46 million kilometres. That is the equivalent of circumnavigating the Earth 1,015 times or travelling to the moon and back 60 times. Similarly, the cumulative distance travelled by the 6.7 million animals travelling on these same journeys is 283 million kilometres, which is equivalent to the distance to the sun and back. It would take more than 15 min travelling at the speed of light to cover this distance.

Many of the movement events shown in red (moves to and from markets as well as between farms), and which are of most concern in the spread of cattle diseases, appear to pulsate. This is driven by the days on which markets operate, Monday to Saturday (Fig. 4). In these movement events, the points which appear to represent very intense levels of activity are in most cases markets. The concentration of market and farm to farm sales in the spring and autumn, which contrasts with the fairly uniform distribution of low risk disposals, is discernible as the animation progresses over the course of the year. The slow, low altitude scene from January 23rd to January 30th illustrates the variation in movement over the course of a week, the lack of Sunday trading being very evident. 


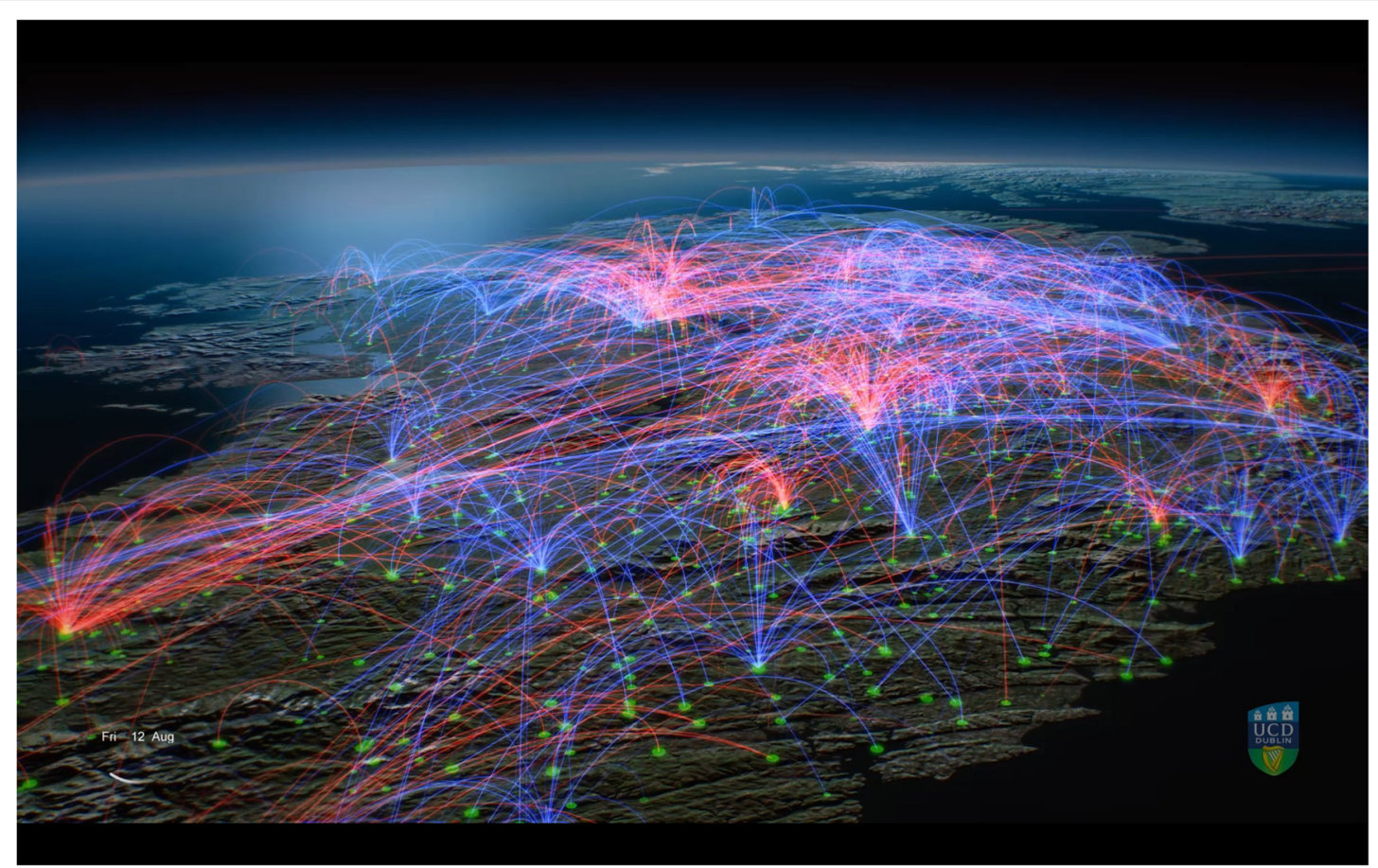

Fig. 1 Screenshot of an animation showing cattle movement events (for example, the movement of a trailer, which may contain a number of cattle) in Ireland. Red lines represent 'High Risk' moves, those where animals are traded between herds in Ireland (including trade via a market), as well as a small number of imports; blue lines represent 'Low Risk' - moves to slaughter or an export point. In this study, a movement from farm to market and subsequent onward movement to farm was counted as two movement events

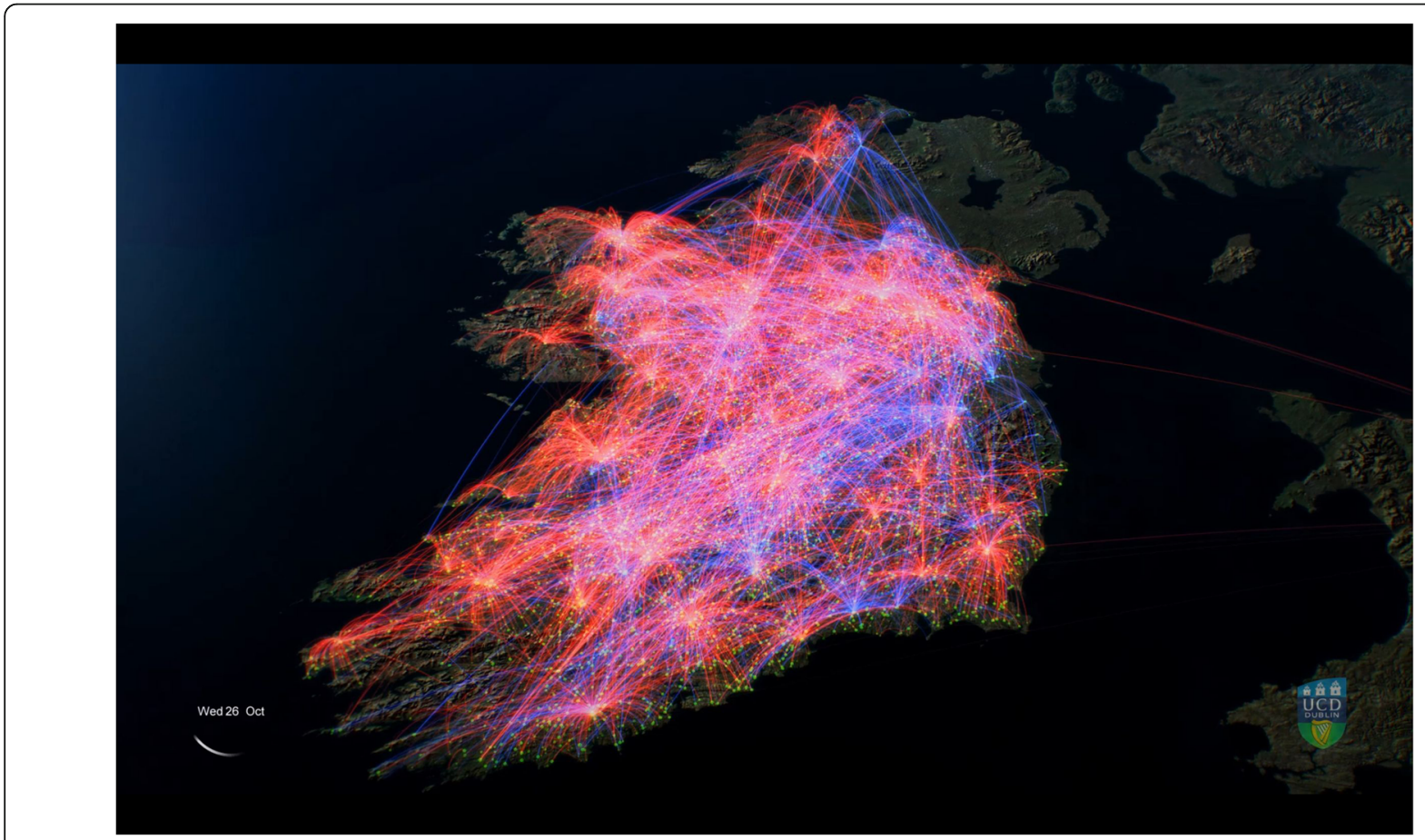

Fig. 2 Screenshot of an animation showing cattle movement events (for example, the movement of a trailer, which may contain a number of cattle) in Ireland. Red lines represent 'High Risk' moves, those where animals are traded between herds in Ireland (including trade via a market), as well as a small number of imports; blue lines represent 'Low Risk' - moves to slaughter or an export point. In this study, a movement from farm to market and subsequent onward movement to farm was counted as two movement events 


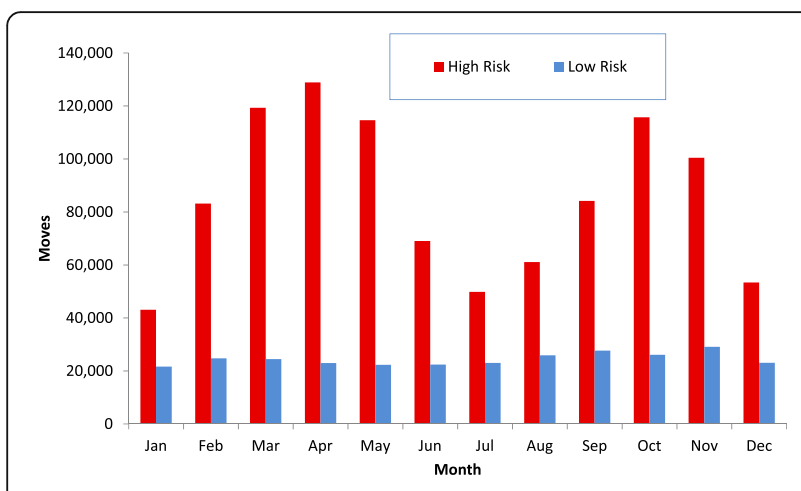

Fig. 3 Number of cattle movement events (moves; for example, the movement of a trailer - which may contain a number of cattle from farm to market) in Ireland, by month, and by risk category, during 2016. 'High Risk' moves represent moves where animals are traded between herds in Ireland (including trade via a market), as well as a small number of imports; whereas 'Low Risk' moves represent moves to slaughter or an export point. In this study, a movement from farm to market and subsequent onward movement to farm were counted as two movement events

It is clear from this animation that many movements cover very large distances, in some cases almost the entire length or breadth of Ireland. These long-range movements are often to abattoirs, suggesting the existence of relatively high purchase prices attracting herd owners away from facilities closer to home.

It can be difficult to present this information in a manner that is interesting and arresting, both for farmers and the industry more broadly, hence, the decision to visually represent these movement data. Data visualisation is being used extensively to assist farmers with other areas of decision-making, for example, to

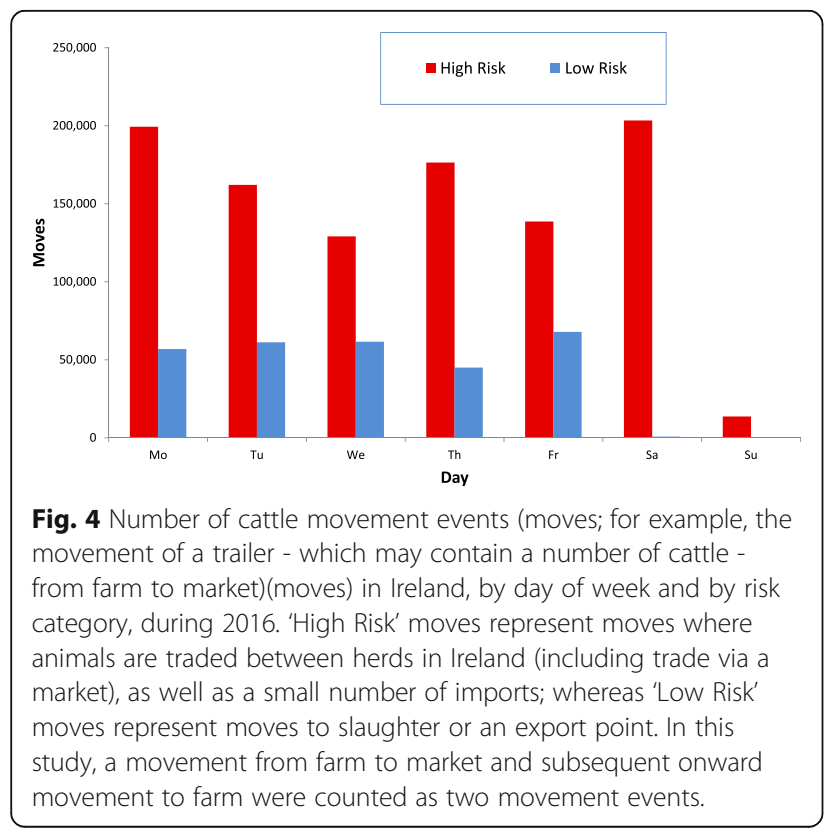

communicate the likely impact of climate change on land use [29]. We are not aware of earlier similar approaches in this field, and hope that this animation will be a valuable communication tool to enable stakeholders to appreciate the role that live cattle movements may play in the transmission of disease. Further, we hope that this animation will stimulate interest in the spatial and temporal patterns of Irish cattle movements. Work is currently being undertaken to compare Irish cattle movements with those from 11 other European countries, as well as a more detailed examination of the spatiotemporal patterns of movements in Ireland, and their implications for the control and monitoring of diseases of livestock. Further work is also planned on the role of cattle movements in the spread of specific diseases, each highly relevant to Ireland, including paratuberculosis, bovine tuberculosis and bovine viral diarrhoea.

\section{Acknowledgements}

Movement data were provided by DAFM AIM division. Data visualisation was undertaken by 422 South (Bristol, UK).

\section{Availability of data and materials}

Annual movement data statistics are available from the Department of Agriculture, Food and the Marine https://www.agriculture.gov.ie/ animalhealthwelfare/animalidentificationmovement/ (accessed May 2018). Summary data may be requested from the corresponding author subject to data protection limitations.

\section{Authors' contributions}

GM designed and coordinated the overall project. GM, JT and SM wrote the manuscript. JT processed and extracted the movement data, GM created the spatial components. All authors read and approved the final manuscript.

\section{Ethics approval and consent to participate}

The study conformed to guidelines of the Human Research Ethics Committee at University College Dublin (UCD), permitting exemption from full ethical review.

\section{Consent for publication}

The authors provide consent for the publication of this material.

\section{Competing interests}

The authors declare that they have no competing interests.

\section{Publisher's Note}

Springer Nature remains neutral with regard to jurisdictional claims in published maps and institutional affiliations.

Received: 25 May 2018 Accepted: 26 August 2018

Published online: 07 September 2018

\section{References}

1. Logan P. Fair day: the story of Irish fairs and markets. Belfast: Appletree Press; 1986.

2. Cronin DA, Gilligan J, Holton K, editors. Irish fairs and markets: studies in local history. Dublin: Four Courts Press; 2001.

3. Wray C, Todd N, McLaren IM, Beedell YE. The epidemiology of Salmonella in calves: the role of markets and vehicles. Epidemiol Infect. 1991;107(3):521-5.

4. Step DL, Krehbiel CR, Depra HA, Cranston JJ, Fulton RW, Kirkpatrick JG, et al. Effects of commingling beef calves from different sources and weaning protocols during a forty-two-day receiving period on performance and bovine respiratory disease. J Anim Sci. 2008;86(11):3146-58. 
5. Ishizaki H, Kariya Y. Road transportation stress promptly increases bovine peripheral blood absolute NK cell counts and cortisol levels. J Vet Med Sci. 2010;72(6):747-53.

6. Rautureau S, Dufour B, Durand B. Vulnerability of animal trade networks to the spread of infectious diseases: a methodological approach applied to evaluation and emergency control strategies in cattle, France, 2005. Transbound Emerg Dis. 2011;58(2):110-20.

7. Mee JF, Geraghty T, O'Neill R, More SJ. Bioexclusion of diseases from dairy and beef farms: risks of introducing infectious agents and risk reduction strategies. Vet J. 2012;194:143-50.

8. Sayers RG, Sayers GP, Mee JF, Good M, Bermingham ML, Grant J, et al. Implementing biosecurity measures on dairy farms in Ireland. Vet J. 2013; 197:259-67.

9. Animal Health Ireland. Understanding infectious diseases. An information leaflet for Irish farmers, advisors and vets. 2013. http://animalhealthireland. ie/?page_id=397. Accessed 21 May 2018.

10. Animal Health Ireland. Bioexclusion: keeping infectious diseases out of your herd. An information leaflet for Irish farmers, advisors and vets. 2013. http://animalhealthireland.ie/?page_id=397. Accessed 21 May 2018

11. Animal Health Ireland. Preventing disease spread within your farm: biocontainment. An information leaflet for Irish farmers, advisors and vets. 2015. http://animalhealthireland.ie/?page_id=397. Accessed 21 May 2018.

12. Animal Health Ireland. Purchasing stock: reducing disease risks. An information leaflet for Irish farmers, advisors and vets. 2016. http:// animalhealthireland.ie/?page_id=397. Accessed 21 May 2018.

13. Christley RM, Pinchbeck GL, Bowers RG, Clancy D, French N, Bennett R, Turner J. Infection in social networks: using network analysis to identify high-risk individuals. Am J Epidemiol. 2005;162:1024-31.

14. Robinson SE, Christley RM. Identifying temporal variation in reported births, deaths and movements of cattle in Britain. BMC Vet Res. 2006;2:11.

15. Robinson SE, Christley RM. Exploring the role of auction markets in cattle movements within Great Britain. Prev Vet Med. 2007;81:21-37.

16. Robinson SE, Everett MG, Christley RM. Recent network evolution increases the potential for large epidemics in the British cattle population. J R Soc Interface. 2007:4:669-74.

17. Leslie EEC, Christley RM, Geong M, Ward MP, J-ALML T. Analysis of pig movements across eastern Indonesia, 2009-2010. Prev Vet Med. 2015;118:293-305.

18. Firestone SM, Ward MP, Christley RM, Dhand NK. The importance of location in contact networks: describing early epidemic spread using spatial social network analysis. Prev Vet Med. 2011;102:185-95.

19. Nöremark M, Håkansson N, Lewerin SS, Lindberg ALE, Jonsson A. Network analysis of cattle and pig movements in Sweden: measures relevant for disease control and risk based surveillance. Prev Vet Med. 2011;99:78-90.

20. Guinat C, Relun A, Wall B, Morris A, Dixon L, Pfeiffer DU. Exploring pig trade patterns to inform the design of risk-based disease surveillance and control strategies. Sci Rep-UK. 2016;6:28429.

21. DAFM. AIM Statistics Report; 2016. p. 2017. https://www.agriculture.gov.ie/ media/migration/animalhealthwelfare/animalidentificationandmovement/ AlMStatisticsRpt2016190517.pdf. Accessed 9 May 2018

22. Ashe S, More SJ, O'Keeffe J, White P, McGrath G, Aznar I. Survival and dispersal of a defined cohort of Irish cattle. Ir Vet J. 2009;62:44-9.

23. Tratalos JA, Graham D, More SJ. Patterns of calving and young stock movement in Ireland and their implications for BVD serosurveillance. Prev Vet Med. 2017;142:30-8.

24. Reardon F, Graham DA, Clegg T, Tratalos JA, O'Sullivan P, More SJ. Quantifying the role of Trojan dams in the between-herd spread of bovine viral Diarrhoea virus (BVDv) in Ireland. Prev Vet Med. 2018;152:65-73.

25. Tratalos JA, Thulke H-H, Graham D, Guelbenzu Gonzalo MG, More SJ. Decision support beyond total savings - eligibility and potential savings for individual participants from changes in the national surveillance strategy for bovine viral diarrhoea (BVD) in Ireland. Prev Vet Med. 2018;155:38-44.

26. Thulke $\mathrm{H}-\mathrm{H}$, Lange M, Tratalos JA, Clegg TA, McGrath G, O'Grady L, O'Sullivan P, Doherty ML, Graham DA, More SJ. Eradicating BVD, reviewing Irish programme data and model predictions to support prospective decision making. Prev Vet Med. 2017;150:151-61.

27. Murray GM, Cassidy JP, Clegg TA, Tratalos JA, McClure J, O'Neill RG, Sammin DJ, Casey MJ, McElroyd M, Earley B, Bourke N, More SJ. A retrospective epidemiological analysis of risk factors for a primary necropsy diagnosis of bovine respiratory disease. Prev Vet Med. 2016;132:49-56.
28. Clegg TA, More SJ, Higgins IM, Good M, Blake M, Williams DH. Potential infection-control benefit for Ireland from pre-movement testing of cattle for tuberculosis. Prev Vet Med. 2008;84:94-111.

29. Bishop ID, Pettit CJ, Sheth F, Sharma S. Evaluation of data visualisation options for land-use policy and decision making in response to climate change. Environ Plann B. 2013;40:213-33.

\section{Ready to submit your research? Choose BMC and benefit from:}

- fast, convenient online submission

- thorough peer review by experienced researchers in your field

- rapid publication on acceptance

- support for research data, including large and complex data types

- gold Open Access which fosters wider collaboration and increased citations

- maximum visibility for your research: over $100 \mathrm{M}$ website views per year

At BMC, research is always in progress.

Learn more biomedcentral.com/submissions 